International Research Journal of Management, IT \& Social Sciences
Available online at https://sloap.org/journals/index.php/irjmis/
Vol. 6 No. 3, May 2019, pages: 46 60
ISSN: 2395-7492
https://doi.org/10.21744/irjmis.v6n3.623

\title{
The Effect of Information Technology Relatedness on Union Performance Mediated by Knowledge Management Capability
}

I Made Sukardi ${ }^{\text {a }}$

Article history:

Received: 18 December 2018

Accepted: 31 March 2019

Published: 29 April 2019

\section{Keywords:}

information technology;

knowledge;

management capability;

management;

union performance;

\begin{abstract}
The purpose of this research are: (1) to know the effect of information technology relatedness on knowledge management capability; (2) to know the effect of knowledge management capability on the union performance; (3) to know the effect of information technology relatedness on the union performance; and (4) to know the effect of information technology relatedness on the union performance mediated knowledge management capability. The type of data in this study is the type of qualitative data and quantitative data. The sample used in this research is manager/head of cooperative and manager/head of accounting department at Multipurpose Cooperative in Badung regency of Bali Province using Information Technology Relatedness with Full Integrated System. While the data analysis techniques used using multiple regression analysis. Based on the results of research indicate that: (1) Information technology relatedness have a positive effect on knowledge management capability; (2) Knowledge management capability has a positive effect on union performance; (3) Information technology relatedness has a positive impact on union performance; and (4) Information technology relatedness has a positive influence on the union performance which is mediated by knowledge management capability.
\end{abstract}

2395-7492@ Copyright 2019. The Author. This is an open-access article under the CC BY-SA license (https://creativecommons.org/licenses/by-sa/4.0/) All rights reserved.

\section{Author correspondence: \\ I Made Sukardi, \\ Staff at Koperasi Anugerah Swadana Sejahtera, Bali, Indonesia. \\ Email address: made_sukardi@ymail.com}

\section{Introduction}

The technology of information is currently a very important competitive advantage in determining the competitiveness and ability of a company to improve performance in the future. A company assesses that an investment in technology of information is a way to increase productivity, profitability and operational quality (Devaraj \& Kohli, 2003). In the increasing of the fierce level of competition in the Union/banking industry, the role of information technology in supporting Union operational/banking operations determine the achievement of the success and becoming the competitive advantage (Amrul, 2004).

${ }^{a}$ Udayana University, Bali, Indonesia 
Tanriverdi (2006), tries to conceptualize the sources of the synergy of information technology and the conditions that surround the synergy of the information technology that improves company performance through complementarity four dimensions of information technology relatedness. Complementarity of the four dimensions of information technology relatedness can create the synergy across units within the company and then influence the performance of the company (Tanriverdi 2006).

Union has a role which is known as a different type of company from an individual company, a Limited Liability Company $(L t d)$. Although Union is different from companies, basically the Union still needs management by carrying out management functions in organizational performance both planning functions, organizing functions, implementation functions, and supervisory functions. In addition, it is necessary to analyze the financial performance of the Union which is intended to find out how financial turnover is obtained from savings or from the sale of products so that it can be seen also a problem in the Union whether the income in the Union has decreased or even increased or that Union performance is good or bad.

Union in Badung Regency in improving the performance of the Union must know the capabilities of their resources, management capacity to use intangible resources, which is called knowledge with the aim of achieving the desired final goal, which is called knowledge management capability (Hitt et al., 2001). Improving the performance of the Union also needs to create a conducive atmosphere in work. Healthy working climates and condition are very effective in improving company performance. To achieve this, the company created various policies in the purpose to maximize the potential of its Human Resources (HR).

The increasing of human resources able to carry out better work is very necessary; therefore, most companies have a routine training agenda to support the increase in human resources. This learning process is not only based on general training, but can be done in other forms, such as dialogue, question and answer session, sharing experiences, or documents. Knowledge is the main source of the learning process. Therefore, the development of human resources depends on the knowledge which is learned and has a direct influence on the company itself. Knowledge management can be applied to support the process of developing human resources through a structured knowledge sharing process.

Knowledge management capability is the management capacity to use intangible resources, named knowledge, in the purpose of achieving the desired goals (Hitt et al., 2001). Management knowledge can also enhance the innovation and organizational response to deal with the competition (Hackbarth in Alavi \& Leidner, 2001, Dewi, et al., 2018). The potential of cross-unit management knowledge from a company that has integrated business units can use the coordination mechanism to improve the potential management knowledge capability across units, linking rules, integrated managers, cross-unit groups, task strength, direct contact between managers and others.

Information technology enables knowledge management in developing Union performance; research conducted by researchers on developing the relationship between information technology, knowledge management capability, and the performance of Union is still very little. Systematic empirical testing of these relationships is also rare. In addition, the literature in the field of information systems does not identify many studies that prove the relationship of information technology to knowledge management capability, or knowledge management capability to company performance (Alavi \& Leidner, 2001; Schultze \& Leidner, 2002).

According to Brown \& Magill (1998), the management and regulation of information technology in a company whose business units are integrated has important implications for the company's ability to utilize cross-unit synergy. The concept of cross-business synergy is the center of the company's performance which is integrated with various business portfolios. To increase the potential of cross-unit management knowledge from companies that have integrated business units, a cross-unit coordination mechanism is needed. Companies that have integrated business units can use these coordination mechanisms to improve the mechanism of Knowledge Management Capability across units, linking rules, integrated managers, cross-unit groups, task strength, direct contact between managers, and etc. Galbraith (1973) \& Dedrick et al., (2003), in the results of his research, stated that information technology can be used as a coordination mechanism across units and information technology has an influence on the productive processes of the company in its role as a coordination mechanism.

Based on the research by Tanriverdi (2006), Information Technology Relatedness, Knowledge Management Capability, and Performance of Business Firms show that information technology relatedness of business units enhances knowledge management capability across company units, while knowledge management capability creates and utilizes cross-unit synergy from the product, customer, and managerial knowledge resources. This synergy can improve the company's financial performance. Information technology relatedness also indirectly has a significant influence on company performance through knowledge management capability as mediation. Tanriverdi (2006), obtained evidence that information technology relatedness had a positive and significant effect on the performance of multibusiness companies as well as Ifada (2011), in financial institutions.

Sukardi, I. M. (2019). The effect of information technology relatedness on union performance mediated by knowledge management capability. International Research Journal of Management, IT and Social Sciences, 6(3), 46-60. https://doi.org/10.21744/irjmis.v6n3.623 
Lestari \& Zulaikha (2014), conducted a study on the effect of information technology relatedness on company performance with knowledge management capability as a variable intervening in banking companies in Central Java. The results of the study state that the four complementary aspects of the relationship of information technology (Information Technology Relatedness) will increase the potential of knowledge management (knowledge management capability). The synergy that arises from products (products), customers (customers), and managerial of knowledge management capability can improve the performance of companies that have integrated business units.

The problems faced by Union in Badung regency that have implemented information technology do not necessarily improve their performance, such as there are several Union that has not been able to calculate the inventory maximally, expired items, and others. The performance of a good information system cannot always improve the performance of the Union. However, most Union in Badung Regency recognizes that the application of information technology systems helps to improve company performance (source: preliminary observation). This is what attracts researchers to conduct this research.

The considerations above are the motivation to examine the effect of information technology relatedness and knowledge management capability on Union performance, and the effect of information technology relatedness with knowledge management capability as the mediating variable on the performance of Union using the Full Integrated System IT. Full Integrated System is used for cross-unit synergies of Union product, customer, and managerial knowledge resources.

\section{Research Problem}

a) Does information technology relatedness affect knowledge management capability?

b) Does knowledge management capability affect the performance of the Union?

c) Does information technology relatedness affect the performance of the Union?

d) Does information technology relatedness affect the Union's performance mediated by knowledge management capability?

\section{Materials and Methods}

Theoretical Framework
a) Theory Goal Settings
b) Information Technology Relatedness
c) Knowledge Management Capability
d) Union Performance

Thinking Framework, Research Concept, and Hypothesis

Thinking Framework

Sekaran (1992), states that the thinking framework is a conceptual model that describes the relationship of theory with the variables that have been identified as research problems. The thinking framework defines the relevance between independent and dependent variables in accordance with the theory described. The thinking framework of this study can be seen in Figure 1. 


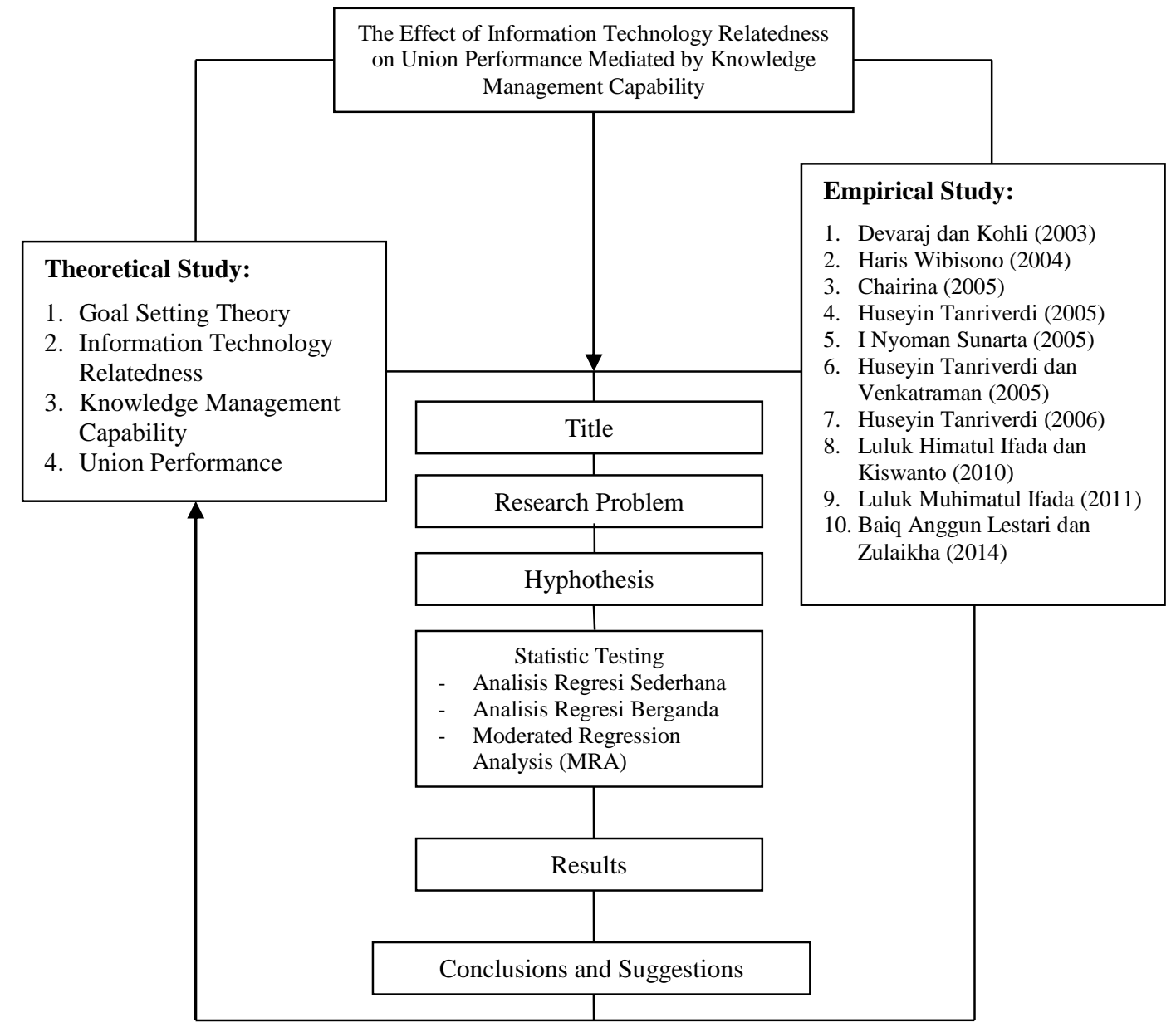

Figure 1. Thinking Framework

\section{Research Concept}

The research concept is technical terminology which is the components of the theoretical framework. The conceptual framework can be in the form of a chart, mathematical model, or functional formulation, which is equipped with qualitative descriptions and shows all the variables that influence the research. The concept of this research can be seen in Figure 2.

Sukardi, I. M. (2019). The effect of information technology relatedness on union performance mediated by knowledge management capability. International Research Journal of Management, IT and Social Sciences, 6(3), 46-60. https://doi.org/10.21744/irjmis.v6n3.623 


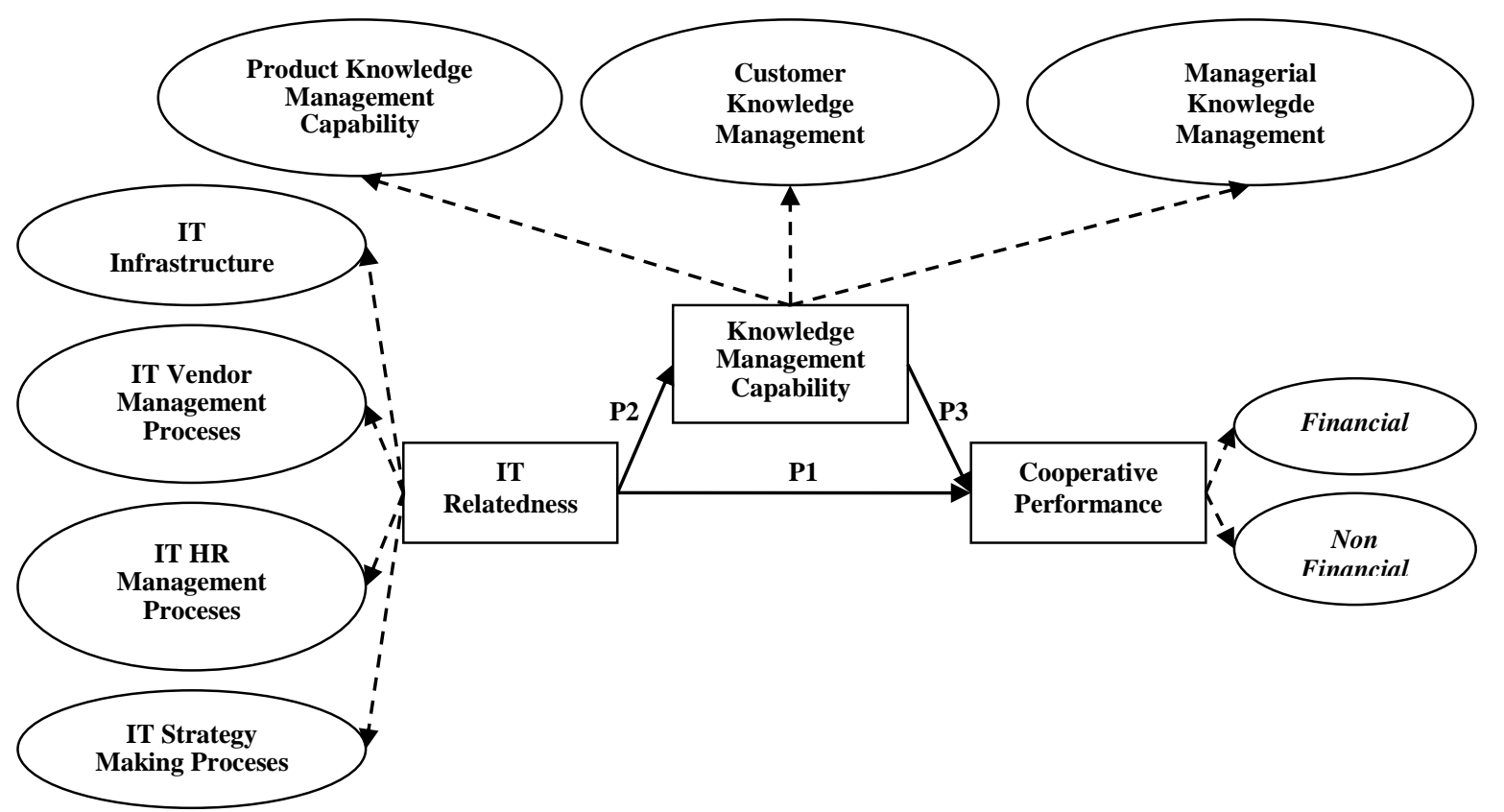

Figure 2. Research concept

Hypothesis

The Effect of Information Technology Relatedness on Knowledge Management Capability

Tanriverdi (2006), found that when one aspect of information technology relatedness has poor performance, it will negatively affect other aspects, including performance in a system that tends to decrease so that it can hinder crossunit knowledge management capability. Schulze \& Liedner (2002), concluded that IT can improve knowledge management capability. The results of this study are supported by the research from Tanriverdi (2005), which shows information technology relatedness has a positive influence on the knowledge management capability, which means that the synergy of information technology relatedness of business units improves knowledge management capability across company units.

Based on the description above, the researcher agrees with the findings of the two studies which state that information technology relatedness influences the knowledge management capability. Therefore, in the study, researchers proposed the $\mathrm{H} 1$ hypothesis as follows:

H1: Information technology relatedness has a positive effect on knowledge management capability.

\section{The Effect of Knowledge Management Capability on Union Performance}

Research by Tanriverdi (2006), found that increasing synergy of super-additive values arising from the use of complementarity units from the knowledge management capability has a positive influence on the performance of the Union. When competitors are able to observe that the individual knowledge capability dimension is able to create and utilize synergy. The dimensions of product knowledge related to the use of knowledge of research and development and similar operations between business units, relatedness dimensions of customer knowledge such as the use of marketing skills and knowledge that are the same among business units, managerial knowledge relatedness dimensions such as the use of the same managerial policies and processes. However, the synergy that arises from the relatedness of knowledge is not the same as the synergy arising from complementary knowledge.

Harrison et al., (2001), concluded that the synergy arising from complementary knowledge is not easy for competitors to observe, perhaps it will lack a strategic review in the future to recognize the three types of complementary knowledge and they must set up a complementary knowledge management capability. Even if they recognize complementary, competitors will face various difficulties related to the implementation costs because they must make systemic changes for all dimensions of knowledge management capability simultaneously.

Apply individual knowledge management capability without applying other dimensions will not produce the expected performance. Porter (1996); Milgrom and Robert (1995); and Tanriverdi \& Venkatraman (2005), reveal that this can actually reduce the performance. Therefore, an increasing of Union performance is expected to increase, 
depending on the complementary application of three dimensions of knowledge management capability in products, customers, and company managerial knowledge.

Based on the description above, the researcher agrees with the results of these studies which state that knowledge management capability influences the performance of the Union. Therefore, in this research, the researcher proposed the $\mathrm{H} 2$ hypothesis as follows:

$\mathrm{H} 2$ : Knowledge management capability has a positive effect on Union performance.

\section{The Effect of Information Technology Relatedness on Union Performance}

Research by Tanriverdi \& Venkatraman (2005), concludes that increased synergy from complementary resources is more difficult to observe and emulate when compared to the synergies arising from resource relatedness. Meanwhile, the research of Milgrom \& Robert (1995), found that competitors generally lack strategic review into the future to recognize complementary. Ifada (2011), shows that even if competitors are successful in the future to recognize complementary, then imitate it successfully, competitors must make systemic changes in all four dimensions of the information technology relatedness of business units simultaneously. The research of Milgrom \& Robert (1995), states that it is related to complementary, the failure of implementation in a dimension will negatively affect the failure of the implementation of other dimensions, thus pushing in the direction of the failure of the overall attempt to imitate. The influence of information technology relatedness on Union performance depends on the complementarity of the four dimensions of information technology relatedness.

Based on the description above, researchers agree with the results of these studies which state that information technology relatedness influences the performance of the Union. Therefore, in this research, the researcher proposed the H3 hypothesis as follows:

H3: Information technology relatedness has a positive effect on Union performance.

The Effects of Information Technology Relatedness on Union Performance Mediated with Knowledge Management Capability

Understanding of knowledge management capability for product, customer and managerial units among business units increases, company will utilize the knowledge complementarity resources and implied and be managed with certain processes so it can form cross-unit knowledge synergy which is a synergy of super-additive values (Muhammad et al., 2012). The emergence of cross-unit knowledge synergy is not easy to be observed and imitated by competitors because it provides unique values as a unit of complementary resources and can be a competitive sustainability advantage to be able to improve the performance of a company (Pebrianto et al., 2013; Shing et al., 2006). Lestari \& Zulaikha (2014), found that knowledge management capability can be an intermediary between information technology and performance as well as Tanriverdi (2006), stating capability knowledge management to be a mediator between information technology relatedness and performance.

Based on the description above, the researcher agrees with the results of these studies which state that information technology relatedness influences Union performance mediated by knowledge management capability. Therefore, the study researcher proposed the $\mathrm{H} 4$ hypothesis as follows:

H4: Information technology relatedness has a positive effect on Union performance mediated by knowledge management capability.

\section{Results and Discussions}

Descriptive Analysis Results

Descriptive Analysis Results of Variable Information Technology Relatedness (X1)

The results of the descriptive analysis of the information technology relatedness variable are divided into several indicators; they are information technology infrastructure, information technology vendor management processes, information technology HR management processes and information technology strategy-making processes. Examples of the calculations are as follows:

The frequency of respondents' answers along with the scores of questions on information technology infrastructure indicators can be seen as follows:

Sukardi, I. M. (2019). The effect of information technology relatedness on union performance mediated by knowledge management capability. International Research Journal of Management, IT and Social Sciences, 6(3), 46-60. https://doi.org/10.21744/irjmis.v6n3.623 
Table 1

Descriptive analysis results on indicators of information technology infrastructure $\mathrm{N}=64$

\begin{tabular}{ccccccc}
\hline \multirow{2}{*}{ No. } & \multicolumn{7}{c}{ Frequency of Answers } & \multirow{2}{*}{ Total } \\
& 1 & 2 & 3 & 4 & 5 & \\
\hline P1 & 3 & 13 & 7 & 29 & 12 & 64 \\
P2 & 2 & 3 & 13 & 35 & 11 & 64 \\
P3 & 2 & 13 & 7 & 36 & 6 & 64 \\
P4 & 2 & 13 & 9 & 29 & 11 & 64 \\
P5 & 3 & 6 & 12 & 33 & 10 & 64 \\
Total & 12 & 48 & 48 & 162 & 50 & 320 \\
\hline & \multicolumn{7}{c}{ Score Answer } & & & Total \\
No. & 1 & 2 & 3 & 4 & 5 & \\
& 3 & 26 & 21 & 116 & 60 & 226 \\
P1 & 2 & 6 & 39 & 140 & 55 & 242 \\
P2 & 2 & 26 & 21 & 144 & 30 & 223 \\
P3 & 2 & 26 & 27 & 116 & 55 & 226 \\
P4 & 3 & 12 & 36 & 132 & 50 & 233 \\
P5 & 12 & 96 & 144 & 648 & 250 & 1150 \\
Total & \multicolumn{7}{r}{}
\end{tabular}

Interval range for 5 questions with 64 respondents:

$$
\begin{aligned}
\text { Minimum Index Value } & =\text { Minimum Score x Number of Questions x Number of Respondents } \\
\text { Maximum Index Value } & =1 \times 5 \times 64=320 \\
& =5 \times 5 \times 64=1600 \\
\text { Interval } & =\text { Maximum Index Value - Minimum Index Value } \\
& =1600-320=1280 \\
\text { Interval Range } & =\text { Interval : level (5) } \\
& =1280: 5=256
\end{aligned}
$$

Furthermore, the total score of respondents' answers from information technology infrastructure indicators is plotted on the interval line, the following results are obtained:

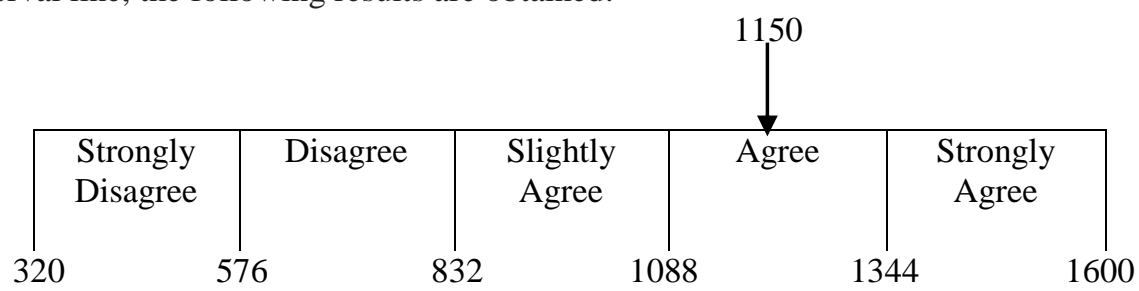

Source: Nazir (2002)

Based on these interval results, it provides a general picture that information technology infrastructure indicators are in the "Agree" category with a total score of 1150. From the result above it can be stated that technology infrastructure makes the employees have the opportunity to manage their work, workers' expertise also supports technology infrastructure in accordance with the work that the workers do.

Then the results of the descriptive analysis for the indicators of the Information Technology Relatedness variable (X1) can be seen in the following table: 
Table 2

The variables of information technology relatedness $\left(\mathrm{X}_{1}\right)$

\begin{tabular}{|c|c|c|c|c|}
\hline \multirow{2}{*}{ No. } & \multicolumn{4}{|c|}{ The Variables of Information Technology Relatedness $\left(\mathrm{X}_{1}\right)$} \\
\hline & Indicator & Score & Category & Description/Narration \\
\hline 1 & $\begin{array}{l}\text { Information } \\
\text { technology } \\
\text { infrastructure }\end{array}$ & 1150 & Agree & $\begin{array}{l}\text { Information technology infrastructure } \\
\text { indicators are in the "Agree" category } \\
\text { with a total score of } 1150 \text {. From this, } \\
\text { it can be stated that technology } \\
\text { infrastructure makes employees have } \\
\text { the opportunity to manage their work, } \\
\text { the expertise of workers also supports } \\
\text { technology infrastructure in } \\
\text { accordance with the work that the } \\
\text { workers do. }\end{array}$ \\
\hline 2 & $\begin{array}{l}\text { Information } \\
\text { technology vendor } \\
\text { management } \\
\text { processes }\end{array}$ & 710 & Agree & $\begin{array}{l}\text { All employees have an opportunity to } \\
\text { be promoted with the improvement of } \\
\text { the performance after technology } \\
\text { infrastructure has been applied. }\end{array}$ \\
\hline 3 & $\begin{array}{l}\text { Information } \\
\text { technology } \\
\text { management } \\
\text { processes }\end{array}$ & 1163 & Agree & $\begin{array}{l}\text { All employees have the opportunity to } \\
\text { be promoted by increasing their } \\
\text { performance after technology } \\
\text { infrastructure has been applied. All } \\
\text { employees can work well with } \\
\text { colleagues in the development of } \\
\text { business units. With the ease of } \\
\text { technology infrastructure, all } \\
\text { employees have the opportunity to } \\
\text { discuss with colleagues in the } \\
\text { development of business units. }\end{array}$ \\
\hline 4 & $\begin{array}{l}\text { Information } \\
\text { technology strategy } \\
\text { making processes }\end{array}$ & 956 & Agree & $\begin{array}{l}\text { Technology infrastructure security } \\
\text { and safety facilities are based on } \\
\text { system planning in the existing } \\
\text { workplaces. Workers also use the } \\
\text { facilities of office technology } \\
\text { infrastructure according to the duties } \\
\text { at the company. }\end{array}$ \\
\hline
\end{tabular}

The Results of the Descriptive Analysis of Knowledge Management Capability (X2)

Furthermore, the results of the descriptive analysis for the indicators of Knowledge Management Capability (X2) variables can be seen in the following Table 3:

Table 3

Knowledge management capability $\left(\mathrm{X}_{2}\right)$

\begin{tabular}{clcccc}
\hline \multirow{2}{*}{ No. } & \multicolumn{4}{c}{ Variable Knowledge Management Capability $\left(X_{2}\right)$} \\
\cline { 2 - 5 } & \multicolumn{1}{c}{ Indicator } & Score & Category & \multicolumn{2}{c}{ Description/Narration } \\
\hline 1 & $\begin{array}{l}\text { Product knowledge } \\
\text { management } \\
\text { capability }\end{array}$ & 921 & Agree & $\begin{array}{l}\text { All employees have additional } \\
\text { knowledge from external sources in } \\
\text { terms of management at the job. }\end{array}$
\end{tabular}

Sukardi, I. M. (2019). The effect of information technology relatedness on union performance mediated by knowledge management capability. International Research Journal of Management, IT and Social Sciences, 6(3), 46-60. https://doi.org/10.21744/irjmis.v6n3.623 


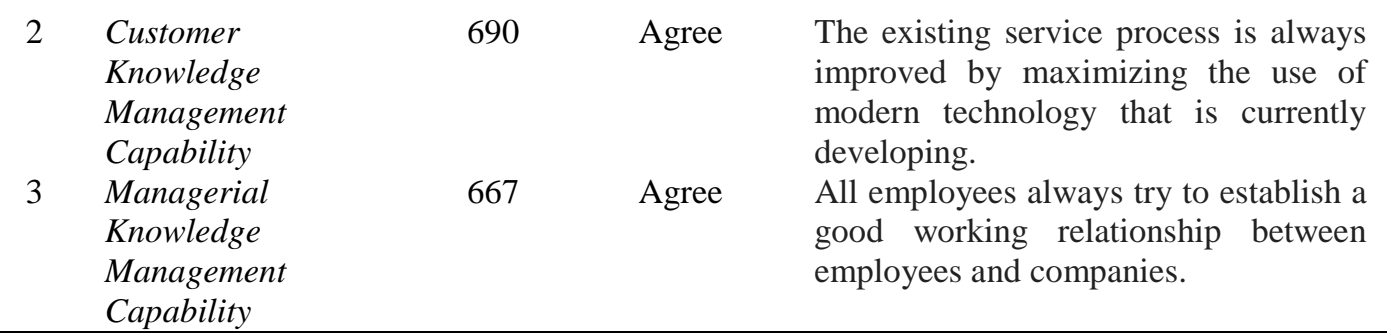

The Results of the Descriptive Analysis of Union Performance Variables $(Y)$

Then the results of the descriptive analysis for the indicators of the Union Company Performance variable (Y) can be seen in the following table:

Table 4

Union performance variables (Y)

\begin{tabular}{|c|c|c|c|c|}
\hline \multirow{2}{*}{ No. } & \multicolumn{4}{|c|}{ Union Performance Variables } \\
\hline & Indicator & Score & Category & Description/Narration \\
\hline 1 & Financial & 681 & Agree & $\begin{array}{l}\text { Profitability obtained by the company } \\
\text { in a certain period experienced a } \\
\text { significant increase, especially since } \\
\text { the use of information technology } \\
\text { systems. }\end{array}$ \\
\hline 2 & Nonfinancial & 690 & Agree & $\begin{array}{l}\text { Companies that implement well- } \\
\text { integrated information technology } \\
\text { systems will have a wider market } \\
\text { share. }\end{array}$ \\
\hline
\end{tabular}

Path Analysis Results

Structure Regression Analysis 1

The results of the analysis of linear regression structure 1 are intended to analyze the magnitude of the direct influence of the information technology relatedness variable on the knowledge management capability. Then can be seen in the following table:

Table 5

Regression analysis structure 1

\begin{tabular}{|c|c|c|c|c|c|c|}
\hline \multirow[t]{2}{*}{ Model } & & \multicolumn{2}{|c|}{$\begin{array}{l}\text { Unstandardized } \\
\text { Coefficients }\end{array}$} & \multirow{2}{*}{$\begin{array}{c}\begin{array}{c}\text { Standardized } \\
\text { Coefficients }\end{array} \\
\text { Beta } \\
\end{array}$} & \multirow[t]{2}{*}{$\mathrm{t}$} & \multirow[t]{2}{*}{ Sig. } \\
\hline & & B & Std. Error & & & \\
\hline \multirow[t]{2}{*}{1} & (Constant) & 0,034 & 0,294 & & 0,116 & 0,908 \\
\hline & $\begin{array}{l}\text { Information.Technol } \\
\text { ogy.Relatedness }\end{array}$ & 0,964 & 0,079 & 0,839 & 12,130 & 0,000 \\
\hline
\end{tabular}

a Dependent Variable: Knowledge.Management.Capability

$\mathrm{R}^{2}=0,704, ; \mathrm{F}=147,141 ; \mathrm{Sig}=0,000$

Based on the table above, the regression equations obtained are as follows:

$\mathrm{Y}_{1}=0,839 \mathrm{X}$

Information:

$\mathrm{Y}_{1}=$ Knowledge Management Capability

$\mathrm{X}=$ Information Technology Relatedness 
The Results of Regression Analysis Structure 2

The results of multiple regression analysis for structure 2 were analyzed by the SPSS program 25 for windows intended to analyze the magnitude of the direct influence of the information technology relatedness variable and knowledge management capability on the company performance. Next can be seen in the following Table 6:

Table 6

Regression analysis structure 2

\begin{tabular}{|c|c|c|c|c|c|c|}
\hline \multirow[t]{2}{*}{ Model } & & \multicolumn{2}{|c|}{ Unstandardized Coefficients } & \multirow{2}{*}{$\begin{array}{l}\text { Standardized } \\
\text { Coefficients } \\
\text { Beta }\end{array}$} & \multirow[t]{2}{*}{$\mathrm{t}$} & \multirow[t]{2}{*}{ Sig. } \\
\hline & & B & Std. Error & & & \\
\hline \multirow[t]{3}{*}{1} & $\begin{array}{l}\text { (Constant) } \\
\text { Information }\end{array}$ & $-0,122$ & 0,334 & & $-0,366$ & 0,715 \\
\hline & $\begin{array}{l}\text { Technology } \\
\text { Relatedness }\end{array}$ & 0,659 & 0,166 & 0,528 & 3,972 & 0,000 \\
\hline & $\begin{array}{l}\text { Knowledge } \\
\text { Management } \\
\text { Capability }\end{array}$ & 0,360 & 0,144 & 0,331 & 2,493 & 0,015 \\
\hline
\end{tabular}

a Dependent Variable: Union Performance

$\mathrm{R}^{2}=0,681 ; \mathrm{F}=65,110 ;$ Sig. $=0,000$

Based on the table above, the equation of regression structure 2 can be seen as follows:

$\mathrm{Y}_{2}=0,528 \mathrm{X}+0,331 \mathrm{Y}_{1}$

Information:

$\mathrm{Y}_{2}=$ Union Performance

$\mathrm{Y}_{1}=$ Knowledge Management Capability

$\mathrm{X}=$ Information Technology Relatedness

Model Validity Check

The path model validity can be seen from the total coefficient of determination. Before calculating the total coefficient determination, standard error of estimate must be calculated first from each structural equation in the path model.

a) The value of the error of estimate from structural equation 1

$$
\begin{aligned}
& e 1=\sqrt{1-R^{2}} \\
& e 1=\sqrt{1-0,704} \\
& \mathrm{e} 1=0,54
\end{aligned}
$$

b) The value of the error of estimate from structural equation 2

$$
\begin{aligned}
& e 2=\sqrt{1-R 2^{2}} \\
& e 2=\sqrt{1-0,681} \\
& \text { e2 }=0,56
\end{aligned}
$$

The total determination value is calculated by the following formula:

$$
\begin{aligned}
& \mathrm{R}_{\mathrm{m}}^{2}=1-\mathrm{e}_{1} \mathrm{e}_{2} \\
& \mathrm{R}_{\mathrm{m}}{ }^{2}=1-(0,54 \times 0,56) \\
& \mathrm{R}_{\mathrm{m}}{ }^{2}=0,70
\end{aligned}
$$

The total coefficient of determination is 0.70 , explaining that $70 \%$ of Union performance is determined by variables in the model (Information Technology Relatedness and Knowledge Management Capability) while the remaining 30\% is determined by variables outside the model. This value indicates that the model is valid and acceptable.

Sukardi, I. M. (2019). The effect of information technology relatedness on union performance mediated by knowledge management capability. International Research Journal of Management, IT and Social Sciences, 6(3), 46-60. https://doi.org/10.21744/irjmis.v6n3.623 
Setting the Path Coefficient

Path coefficients consist of direct effects, indirect effects, and total effects. The value of each path coefficient is shown in Table 7.

Table 7

Path coefficient

\begin{tabular}{cccc}
\hline Path & Direct Effects & Indirect Effects & Total Effects \\
\hline $\mathrm{X}-\mathrm{Y}_{1}$ & 0,839 & - & 0,839 \\
$\mathrm{Y}_{1}-\mathrm{Y}_{2}$ & 0,331 & - & 0,331 \\
$\mathrm{X}-\mathrm{Y}_{2}$ & 0,528 & 0,278 & 0,806 \\
\hline
\end{tabular}

The Result of Path Analysis Diagram

Based on the previous discussion, it can be made from the path diagram as shown in Figure 3 below.

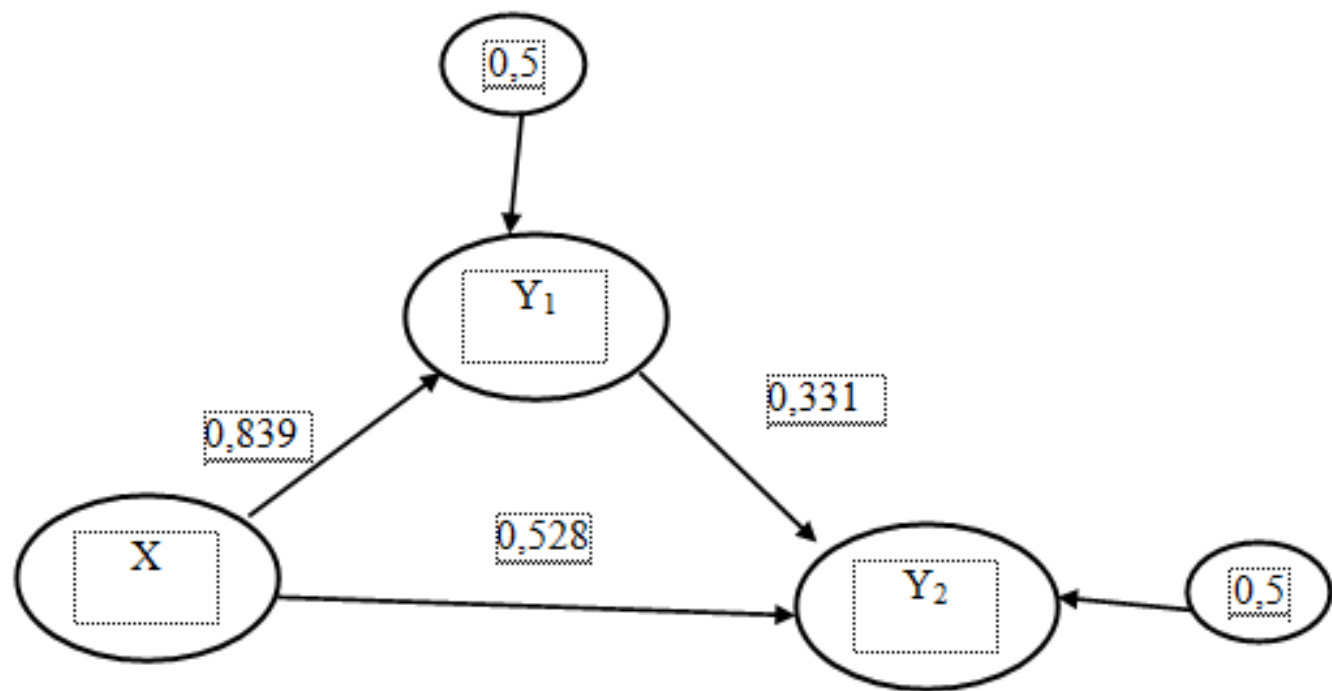

Figure 3. The result of a path analysis diagram

Hypothesis testing

Based on Table 5, the results of the hypothesis test can be described as follows:

1) Effect of Information Technology Relatedness on Knowledge Management Capability

Based on table 5 it can be seen that the value of the Information Technology Relatedness path coefficient on Knowledge Management Capability is 0.839 with a probability/significance or sig value is 0,000 or smaller than 0.05 or $5 \%$. In addition, based on the results of the analysis, the value of $t$-count is 12.130 , which is greater than the $\mathrm{t}$ table of 1.969 . Because sig $<0.05$ and the value of $\mathrm{t}$-count are greater than $\mathrm{t}$-table, it is said that the hypothesis which mentions the Information Technology Relatedness has a positive and significant effect on Knowledge Management Capability can be proven.

The company requires a process of applying the four dimensions of information technology relatedness simultaneously among business units as competitive sustainability of the company's advantage in creating a synergy of super-additive values. This can help to develop the company's understanding of the needs of product knowledge, customer knowledge, and managerial knowledge among business units so it enables the influence of information technology relatedness based on the mechanism that can improve the knowledge management capability across units.

When one aspect of information technology relatedness experiences poor performance, it will negatively affect other aspects, including performance in the system which tends to decrease so that it can inhibit knowledge management capability across units (Tanriverdi, 2006). Researchers in the field of information systems state that IT can improve knowledge management capability (Schultze \& Leidner, 2002). Tanriverdi (2005), research shows 
that information technology relatedness has a significant positive effect on knowledge management capability, which means a synergy of information technology relatedness of business units, improve knowledge management capability across company units.

2) The Effect of Knowledge Management Capability on Union Performance

Based on table 5, it can be seen that the influence of the path coefficient of Knowledge Management Capability on Union Performance is 0.331 with a probability value (significance) of 0.015 or smaller than 0.05 or $5 \%$. In addition, based on the results of the analysis, the value of $\mathrm{t}$-count is 2.493 which is greater than the value of $\mathrm{t}$-table of 1.969. Because sig $<0.05$ and the calculated $t$-value are greater than t-table, it is said that the hypothesis that Knowledge Management Capability has a positive and significant effect on Union performance can be proven.

The increasing of the synergy of the value of super-additives arising from the use of the complementarity unit from the knowledge management capability has a significant influence on company performance (Tanriverdi, 2006). When competitors are able to observe that the individual knowledge capability dimension is able to create and utilize synergy. The dimensions of relatedness product knowledge to the use of knowledge of research and development and the same operations between business units, relatedness customers knowledge dimensions such as the use of marketing skills and knowledge that are the same among business units, dimensions of relatedness managerial knowledge such as the use of the same policies and processes. However, the synergy that arises from the relatedness of knowledge is not the same as the synergy arising from complementary knowledge.

\section{3) The Effect of Information Technology Relatedness on Union Performance}

Based on table 5, it can be seen that the value of path coefficient of the Information Technology Relatedness on Union Performance is 0.528 with a probability value (significance) of 0,000 or smaller than 0.05 or $5 \%$. In addition, based on the results of the analysis, it was obtained that the $t$-count of 3.972 was greater than the $t$ table value of 1.969. Because sig $<0.05$ and the value of $t_{\text {-count }}$ are greater than $\mathrm{t}$-table, it is said that the hypothesis which states Information Technology Relatedness has a positive and significant effect on Union Company Performance can be proven.

Company performance covers the overall performance of the company so that it can produce an objective measure of performance (Govindarajan \& Fisher 1990). This instrument was developed by Govindarajan \& Fisher (1990), in the form of a perceived performance by comparing the performance which is achieved at this time and the performance standards that have been targeted by the company. The increasing of synergy from complementary resources is far more difficult to observe and emulate when compared to the increasing of synergy from resource relatedness (Tanriverdi \& Venkatraman, 2005). Generally, the Competitors lack strategic review in the future to recognize complementary (Milgrom \& Robert, 1995). Even if the competitor is successful in the future to recognize complementary, then imitates it successfully, competitors must make systemic changes in the four dimensions of the information unit relatedness of the business unit simultaneously (Ifada, 2011).

4) The Effect of Information Technology Relatedness on Union Performance Mediated with Knowledge Management Capability

Based on the Regression Analysis Structure 1 and Regression Report Structure 2 are obtained a value $=0.839$; $\mathrm{sa}=0.079 ; \mathrm{b}=0.331$ and $\mathrm{sb}=0.144$. If these values are substituted on the Sobel formula, then $\mathrm{Z}$ value of 2.237 is obtained. The $\mathrm{Z}$ value of 2.237 is greater than the value of $\mathrm{Z}$ table, 1.96 so that it can be concluded that the Knowledge Management Capability (Y1) variable is proven to significantly mediate the effect of Information Technology Relatedness (X1) on Union Performance (Y2).

Understanding of knowledge management capability for a product, customer and managerial units among business units increases, the companies will utilize the knowledge complementarity which is implied and managed with certain processes to form cross-unit knowledge synergy which is a synergy of super-additive values (Muhammad et al., 2012). The emergence of cross-unit knowledge synergy is not easy to be observed and imitated by competitors because it provides unique values as a unit of complementary resources and can be a competitive sustainability advantage to improve company performance (Pebrianto et al., 2013; Shing et al., 2006).

Barua and Mukhopadhyay in Lestari et al., (2014), found that knowledge management capability can be an intermediary between information technology and performance as well as Tanriverdi (2006), stating that knowledge management capability as a mediator between information technology relatedness and Union performance.

Sukardi, I. M. (2019). The effect of information technology relatedness on union performance mediated by knowledge management capability. International Research Journal of Management, IT and Social Sciences, 6(3), 46-60. https://doi.org/10.21744/irjmis.v6n3.623 


\section{Conclusion}

Based on the formulation of the problem, the purpose of the research and the research hypothesis, as well as the results and discussion of the research, can be concluded the followings below:

1) Information technology relatedness has a positive effect on knowledge management capability. The company requires a process of implementing information technology relatedness simultaneously between business units. This can help to develop the company's understanding of the needs of product knowledge, customer knowledge, and managerial knowledge among business units to enable the influence of information technology relatedness based on mechanisms that can improve knowledge management capability across units.

2) Knowledge management capability has a positive effect on Union performance. Increasing the synergy of the value of super-additives arising from the use of the complementarity unit from the knowledge management capability has a positive influence on the performance of the Union. When competitors are able to observe that the individual knowledge capability dimension is able to create and utilize synergy.

3) Information technology relatedness has a positive effect on Union performance. Union performance covers the overall performance of the company so that the objective performance is produced. Even if the competitors are successful in the future, competitors must make systemic changes in all four dimensions of information technology relatedness simultaneously so that the performance of Union can be improved continually.

4) Information technology relatedness has a positive effect on Union performance mediated by knowledge management capability. This means that the implementation of knowledge management capability can increase the influence of information technology relatedness on Union performance.

\section{Suggestions}

Based on the conclusions above, the suggestions that can be given through the results of this study both to Union management, as well as to the development of further research are as follows:

1) Considering the information technology relatedness has proven to have a positive effect on the knowledge management capability, it is recommended that information technology relatedness is improved by doing coordination and information exchange between parts of the Multipurpose Union which can ultimately improve the understanding of product knowledge, customer knowledge, and managerial knowledge.

2) Considering the knowledge management capability has a positive effect on Union performance, it is advised to all Managers of the Multipurpose Union in Badung Regency, especially Managers / Head of Accounting to improve their managerial abilities which at the end can improve the performance of the Union.

3) Considering that information technology relatedness has a positive effect on Union performance, it is advisable to always improve information technology relatedness so that Union performance can be improved.

4) Considering the knowledge management capability is able to mediate the influence of information technology relatedness on Union performance, it is suggested that knowledge management capability is always improved by increasing managerial capabilities which can ultimately improve the performance of Union.

\section{Conflict of interest statement and funding sources}

The authors declared that they have no competing interest. The study was financed by personal funding.

\section{Statement of authorship}

The authors have a responsibility for the conception and design of the study. The authors have approved the final article.

\section{Acknowledgments}

The authors would like to acknowledge the editor of IRJMIS for their support, valuable time, and advice in completing the present article. 


\section{References}

Alavi, M., \& Leidner, D. E. (2001). Knowledge management and knowledge management systems: Conceptual foundations and research issues. MIS quarterly, 107-136. https://doi.org/10.2307/3250961

Amrul, S. (2004). Hubungan antara partisipasi dalam pengembangan sistem informasi dengan perkembangan penggunaan teknologi informasi (suatu tinjauan dengan dua faktor kontijensi). Jurnal Bisnis Strategi, 13(2), 109125. https://doi.org/10.14710/jbs.13.2.109-125

Brown, C. V., \& Magill, S. L. (1998). Reconceptualizing the context-design issue for the information systems function. Organization science, 9(2), 176-194. https://doi.org/10.1287/orsc.9.2.176

Dedrick, J., Gurbaxani, V., \& Kraemer, K. L. (2003). Information technology and economic performance: A critical review of the empirical evidence. ACM Computing Surveys (CSUR), 35(1), 1-28. https://doi.org/10.1145/641865.641866

Devaraj, S., \& Kohli, R. (2003). Performance impacts of information technology: Is actual usage the missing link?. Management science, 49(3), 273-289. https://doi.org/10.1287/mnsc.49.3.273.12736

Dewi, I. G. A. A. O., Dewi, I. G. A. A. P., Kustina, K. T., \& Prena, G. D. (2018). Culture of tri hita karana on ease of use perception and use of accounting information system. International Journal of Social Sciences and Humanities, 2(2), 77-86. https://doi.org/10.29332/ijssh.v2n2.131

Galbraith, J. R. (2007). Designing Complex Organizations (Addison-Wesley series on organization development).

Govindarajan, V., \& Fisher, J. (1990). Strategy, control systems, and resource sharing: Effects on business-unit performance. Academy of Management journal, 33(2), 259-285. https://doi.org/10.5465/256325

Harrison, J. S., Hitt, M. A., Hoskisson, R. E., \& Ireland, R. D. (2001). Resource complementarity in business combinations: Extending the logic to organizational alliances. Journal of management, 27(6), 679-690. https://doi.org/10.1177\%2F014920630102700605

Hoskisson, R. E., Hitt, M. A., Johnson, R. A., \& Grossman, W. (2002). Conflicting voices: The effects of institutional ownership heterogeneity and internal governance on corporate innovation strategies. Academy of Management journal, 45(4), 697-716. https://doi.org/10.5465/3069305

Ifada, L. M. (2011). Pengelolaan Knowledge Management Capability dalam Memediasi dukungan Information Technology Relatedness terhadap Kinerja Perusahaan. Jurnal Akuntansi dan Keuangan Indonesia, 8(1), 54-77. http://dx.doi.org/10.21002/jaki.2011.04

Lestari, BAH. \& Zulaikha. (2014). "Pengaruh Information Technology Relatedness terhadap Kinerja Perusahaan dengan Knowledge Management Capability sebagai Variabel Intervening (Kajian Empiris pada Perusahaan Perbankan di Jawa Tengah)". Simponsium Nasional Akuntansi X, 2(2).

Milgrom, P., \& Roberts, J. (1995). Complementarities and fit strategy, structure, and organizational change in manufacturing. Journal of accounting and economics, 19(2-3), 179-208. https://doi.org/10.1016/01654101(94)00382-F

Muhammad, Huda H., Farah, H.M., Samera, A., Ali, N.B. (2012), "The Influence of Knowledge Management Capabilities on Organizational Performance: A Study of Private University in Malaysia”, International Journal of Science and Research, 2(3).

Pebrianto, A., \& Djamhur, S. K. (2013). The influence of information technology capability, organizational learning, and knowledge management capability on organizational performance (a study of banking branches company in Southern Kalimantan province). In Information and Knowledge Management (3(11), pp. 112-120).

Porter, M. (1996). What is Strategy, Harward Business Review. Revista Gula, 74, 94.

Schultze, U., \& Leidner, D. E. (2002). Studying knowledge management in information systems research: discourses and theoretical assumptions. MIS quarterly, 213-242. https://doi.org/10.2307/4132331

Sekaran, U. (2006). Metodologi Penelitian Untuk Bisnis Edisi 4. Jakarta: Salemba Empat.

Singh, S., Chan, Y. E., \& McKeen, J. D. (2006). Knowledge management capability and organizational performance: A theoretical foundation. In Conference at the University of Warwick, Coventry (pp. 1-54).

Tanriverdi, H. (2005). Information technology relatedness, knowledge management capability, and performance of multibusiness firms. MIS quarterly, 311-334. https://doi.org/10.2307/25148681

Tanriverdi, H. (2006). Performance effects of information technology synergies in multibusiness firms. MIS quarterly, 57-77. https://doi.org/10.2307/25148717

Tanriverdi, H., \& Venkatraman, N. (2005). Knowledge relatedness and the performance of multibusiness firms. Strategic management journal, 26(2), 97-119. https://doi.org/10.1002/smj.435

Sukardi, I. M. (2019). The effect of information technology relatedness on union performance mediated by knowledge management capability. International Research Journal of Management, IT and Social Sciences, 6(3), 46-60. https://doi.org/10.21744/irjmis.v6n3.623 


\section{Biography of Author}

\begin{tabular}{|l|l|}
\hline I Made Sukardi was born in Badung, Bali. He finished the last study at Udayana \\
University Master of Accountant. Currently, he is staff at Koperasi Anugerah Swadana \\
Sejahtera, Bali, Indonesia. \\
Email: made_sukardi@ymail.com
\end{tabular}

